\title{
Influence of silver nanoparticles on growth and health of broiler chickens after infection with Campylobacter jejuni
}

Krishna Prasad Vadalasetty ${ }^{1}$, Charlotte Lauridsen², Ricarda Margarete Engberg², Radhika Vadalasetty ${ }^{1}$, Marta Kutwin ${ }^{3}$, André Chwalibog ${ }^{1,3^{*}}$ (i) and Ewa Sawosz ${ }^{3}$

\begin{abstract}
Background: Silver nanoparticles (AgNP) have gained much attention in recent years due to their biomedical applications, especially as antimicrobial agents. AgNP may be used in poultry production as an alternative to the use of antibiotic growth promoter. However, little is known about the impact of oral administration of AgNP on the gut microbiota and the immune system. The aim of the present study was to investigate the effects of AgNP on growth, hematological and immunological profile as well as intestinal microbial composition in broilers challenged with Campylobacter jejuni (C. jejuni).

Results: AgNP did not affect the intestinal microbial profile of birds. The body weight gain and the relative weights of bursa and spleen were reduced when supplemented with AgNP. There was no difference with respect to packed cell volume. However, the plasma concentrations of IgG and IgM were lower in birds receiving AgNP compared to the non-supplemented control group. The expression of TNF- $a$ and NF-kB at mRNA level was significantly higher in birds receiving AgNP.

Conclusions: The application of AgNP via the drinking water in the concentration of $50 \mathrm{ppm}$ reduced broiler growth, impaired immune functions and had no antibacterial effect on different intestinal bacterial groups, which may limit the applicability of AgNP against C. jejuni in broiler chickens.
\end{abstract}

Keywords: Broiler chickens, Silver nanoparticles, Microflora, Immunoglobulins, Gene expression

\section{Background}

In broiler production, different kinds of antimicrobial agents are used for preventing and controlling diseases. Antimicrobials can affect the host intestinal flora, by reducing the colonization of intestinal bacteria, inhibiting the growth of pathogenic microorganisms, and enhancing the immune system, hence preventing diseases and improving animal performance [1-3]. However, the overuse of antimicrobial agents (antibiotics) promotes the emergence of antibiotic resistance in microorganisms [4], being harmful to animal and human health $[5,6]$. For example, resistance to ciprofloxacin in Camplylobacter jejuni (C. jejuni) isolated

\footnotetext{
* Correspondence: ach@sund.ku.dk

${ }^{1}$ Department of Veterinary and Animal Sciences, University of Copenhagen, 1870 Frederiksberg, Denmark

${ }^{3}$ Department of Animal Nutrition and Biotechnology, Warsaw University of Life Sciences, 02-786 Warsaw, Poland

Full list of author information is available at the end of the article
}

from Danish broiler meat increased significantly from $0 \%$ in 2009 to 17\% in 2010 [7]. The use of all antibiotics as growth promoter has been prohibited in the European Union since $2006[2,8]$. Thus, there is a need to find alternatives to antibiotics in poultry production. When the conventional therapies, including antibiotics, anti-inflammatory agents, growth hormones, surgical interventions, and cytotoxic chemotherapies are ineffective in curing poultry infections, it is necessary to explore novel drug compounds. Nanoparticles have been emerging as one of the new treatment options, and their capability of penetrating normally intact physiologic barriers has reached a variety of molecular targets $[9,10]$.

Recent studies on antibacterial materials such as various natural (oils, acids), inorganic antimicrobial agents such as metals $(\mathrm{Ag}, \mathrm{Au}, \mathrm{Cu})$ and metal oxides $\left(\mathrm{ZnO}, \mathrm{SiO}_{2}, \mathrm{Fe}_{2} \mathrm{O}_{3}\right.$, $\mathrm{TiO}_{2}$ ) have received increasing attention. Among metal 
nanoparticles, silver is one of the most promising components in several nanotechnology products. Currently, there are several consumer products containing various silver nanoparticles (AgNP) because of their antimicrobial properties [11-14]. AgNP have been shown to have a wide range of antibacterial activities against both Gram-positive and Gram-negative bacteria, including major foodborne pathogens [15-19]. At present, there is no study available on their antibacterial effect against $C$. jejuni being a leading cause of human gastroenteritis worldwide. It is mainly transmitted from contaminated chicken meat. Campylobacter infections are associated with the neurological disorder Guillain-Barre syndrome [20, 21]. A common feature of $C$. jejuni causes enterocolitis and is involved in acute inflammatory response that can lead to tissue damage and may be responsible for many of the clinical symptoms [22]. Furthermore, antimicrobial resistance was observed in C. jejuni and Campylobacter coli [23].

Although the antimicrobial effect of AgNP has been studied extensively, the mechanism of antibacterial activity specific to bacteriostatic or bactericidal activity remains unclear. Studies had shown that AgNP upon contact with water can release $\mathrm{Ag}+$ ions from their surface [24]. Free $\mathrm{Ag}+$ has a potent antimicrobial effect, which destroys microorganisms immediately by blocking the cellular respiration and disrupting the function of bacterial cell membranes. This occurs when $\mathrm{Ag}+$ binds to tissue proteins, causing structural changes in the bacterial cell membranes which, in turn, cause cell death. Essential protein complexes of the bacterial electron transport chains are located on the cell exterior and, therefore, are manageable for inactivation by reactive silver ions. $\mathrm{Ag}+$ also binds and denatures the bacterial DNA and RNA, thus inhibiting cell replication [25]. Recently, evidence has been obtained suggesting that silver nanoparticles may modulate the phosphotyrosine profile of putative bacterial peptides that could affect cellular signaling and, therefore, inhibit the growth of bacteria [26].

In recent years, several studies have been focused on anti-inflammatory therapy and on molecules which could block pro-inflammatory pathways. Nanoparticles of Ag and $\mathrm{Au}$ are considered anti-inflammatory agents or components of anti-inflammatory molecules [27, 28]. Moreover, in vivo studies with chicken embryos and quails showed that AgNP did not affect growth, development [29] and DNA oxidative damage to chicken embryos [30]. Results from toxicological assays have shown no in vitro cytotoxicity of AgNP (0.1, 0.5 and 1.0\%) [17] but concentrations $(2.5-50 \mu \mathrm{g} / \mathrm{mL})$ of AgNP exert a cytotoxicity effect on human mesenchymal stem cells [31]. The most common health effects associated with chronic exposure to silver are a permanent grey or blue-grey discoloration of the skin (argyria). From the immunological perspective, it is known that phagocytosis of AgNP stimulates inflammatory signaling through the generation of reactive oxygen species (ROS) in macrophage cells, followed by the activated macrophage cell-induced secretion of TNF- $\alpha$. The increase of TNF- $\alpha$ level causes damage to the cell membrane and apoptosis [32]. An inadvertent recognition of AgNP as a foreign particle by the immune cells may result in a multilevel immune response and finally lead to toxicity in the host. However, when the AgNP are recognized as self or an absence of immune recognition, then their ability to stimulate immune response may decide the fate of AgNP in the host. In vivo studies have demonstrated that nanoparticles are capable of promoting inflammation or suppressing immune functions [33-35]. The nanoparticle-induced inflammatory response may have an impact on immune defense, and the T-helper 1 (Th1)/T-helper 2 (Th2) balance $[9,36]$.

There are limited data regarding the effect of orally administered AgNP on the intestinal bacterial population and immune system of animals. In this study, we hypothesized that the antimicrobial properties of colloidal solutions of AgNP may affect the microbial population and immune responses upon challenge. The use of AgNP in poultry production may potentially function as an alternative to the use of antibiotic based growth promoters. The objective of this study was to investigate the effect of AgNP on the growth, the microbial profile of digestive tract and the immune status of broilers exposed to $C$. jejuni infection. In this study, we used hydrocolloid of AgNP because they exhibit high surface/volume ratio which may effectively enhance the bactericidal activity. In addition, chicks were used as an animal model for bacterial GI infection.

\section{Methods}

\section{Experimental solution}

The hydrocolloid of AgNP obtained from Nano-Tech (Warsaw, Poland) was produced by an electric nonexplosive patented method (Polish Patent 3,883,399) from high purity metals $(99.9999 \%)$ and high purity demineralized water. The concentration of the hydrocolloid was $50 \mathrm{mg} / \mathrm{kg}$ (50 ppm). The shape and size of nanoparticles were inspected by transmission electron microscopy (TEM), the particles had a crystal structure with an average size of $3.5 \mathrm{~nm}$. The average surface area was $2.827 \times 10^{-13} \mathrm{~cm}^{2}$ and the $\mathrm{pH}$ of the colloidal silver solution was 7.1 to 8.1 (data provided by Nano-Tech, Poland). Furthermore, more detailed information regarding the applied AgNP are given by Sawosz et al., 2011 [18].

\section{Experimental design}

Ninety day-old male broiler chickens (Ross 308), obtained from a Danish commercial hatchery (DanHatch, Vrå, Denmark) were used. Upon arrival at the laboratory, the birds were wing-labeled, weighed and randomly distributed to two experimental groups: control, no AgNP, and 
provided with $50 \mathrm{ppm}$ of AgNP in the drinking water. Furthermore, prior to the experiment antibacterial tests were done at in vitro level.

The chickens were housed in six individual isolators with 15 birds per isolator. The room temperature was $32{ }^{\circ} \mathrm{C}$ at the beginning of the experiment and was gradually decreased according to the demands of the growing chickens. The humidity was maintained during the experiment. Over the entire experimental period, both experimental groups were fed the same diet as described in Table 1. Drinking water was provided via nipple drinkers placed in the isolators. Birds were inspected every day and for every 2 days water and fed consumption were recorded. All birds had free access to food and water.

At day 11, all chickens were weighed and cloacal swab samples of 5 chickens per isolator were taken and examined for the presence of $C$. jejuni colonies for initial observation. Subsequently, two birds were randomly selected from each treatment and killed, and then blood samples were collected for packed cell volume (PCV) determination before samples of liver tissue were collected for gene expression studies. Afterwards, the chickens were orally challenged with $0.5 \mathrm{~mL}$ of an overnight culture of $C$. jejuni $\left(4 \times 10^{7} / \mathrm{mL}\right.$ per bird). The infection strain (DVI-sc181) has been isolated from infected commercial broilers and provided by the Technical University of Denmark, National Veterinary Institute.

On days 15, 22 and 30, all chickens were weighed, and 5 chickens per isolator were randomly chosen. Blood samples were taken from the jugular vein and the chickens were immediately sacrificed by cervical dislocation. Liver, heart, spleen and bursa were collected, weighed and stored

Table 1 Composition of the diet for broiler chickens $(\mathrm{g} / \mathrm{kg})$

\begin{tabular}{ll}
\hline Ingredients & \\
\hline Wheat & 49.9 \\
Maize & 10.0 \\
Rape seed (LL), grounded & 4.00 \\
Soybean meal (de-hulled, toasted) & 29.4 \\
Soybean oil & 2.45 \\
Calcium carbonate & 0.90 \\
Monocalcium phosphate & 1.56 \\
Sodium chloride & 0.20 \\
Natrium-bicarbonate & 0.27 \\
Lysine hydrochloride (100\%) & 0.25 \\
DL-Methionine (100\%) & 0.35 \\
Threonine (98\%) & 0.10 \\
Vitamins and minerals & 0.60 \\
(Vitfoss, Slut, 0.5\%) & 100 \\
Total &
\end{tabular}

at $-80{ }^{\circ} \mathrm{C}$ for further analysis. Ileum and caecum were collected to enumerate intestinal bacteria.

\section{Enumeration of Campylobacter and selected groups of intestinal bacteria}

C. jejuni were enumerated in intestinal contents of ileum, caecum and faeces from 5 chickens per isolator at each sampling day. The samples (approximately $3 \mathrm{~g}$ ) were homogenized, and serially diluted in 10-fold in phosphate buffered saline and plated on modified blood free charcoal cefoperazone deoxycholate agar base (Oxoid, CM0739). The plates were incubated with $C$. jejuni specific growth supplements at $42{ }^{\circ} \mathrm{C}$ for $48 \mathrm{~h}$ under microaerobic conditions $\left(5 \% \mathrm{O}_{2}, 5 \% \mathrm{CO}_{2}, 5 \% \mathrm{H}_{2}\right.$, and $\left.85 \% \mathrm{~N}_{2}\right)$. Enterobacteria ( $E$. coli and lactose negative enterobacteria) were enumerated on MacConkey agar (Merck, Darmstadt, Germany, 1.05465) incubated aerobically at $37{ }^{\circ} \mathrm{C}$ for $24 \mathrm{~h}$ as described by Engberg et al. [37]. Lactic acid bacteria (LAB) and Clostridium perfringens were counted respectively on De Man Rogosa Sharpe agar (Merck, 1.10660) incubated anaerobically at $37{ }^{\circ} \mathrm{C}$ for $48 \mathrm{~h}$ and tryptose sulphite cycloserine plates (TSC-Agar, Merck, 1.11072) incubated anaerobically at $37^{\circ} \mathrm{C}$ for $24 \mathrm{~h}$. Enterococci were counted on Slanetz and Bartely plates (Merck, 1.05289) after aerobic incubation at $37{ }^{\circ} \mathrm{C}$ for $48 \mathrm{~h}$. The results are presented as microbial number (CFU/g) in ileal/caecal or faecal material. The detection limit was $10^{2}$ bacteria/g. During the experiment, water samples were collected from the drinkers in the isolators and the antimicrobial effect of AgNP on C. jejuni was investigated in in vitro using the plate count method.

\section{Hematology}

Before cervical dislocation, blood was collected by puncture of the jugular vein in disposable sodium heparinized hematocrit capillary tubes (Camlamb Ltd., Cambridge, UK). The tubes were filled up to two-thirds and sealed with cristaseal (Hawksley, Sussex, UK). The percentage of packed cell volume (PCV) was measured by using a micro-hematocrit reader (Hearaeus Reader, Osterode, Germany).

\section{Concentrations of plasma immunoglobulins}

From 5 chickens, blood samples were drawn from the jugularis vein and were collected in heparinized tubes. Blood samples were subsequently placed on ice, centrifuged at $2000 \mathrm{~g}$ for $10 \mathrm{~min}$ at $4{ }^{\circ} \mathrm{C}$, and the plasma was stored at $-20{ }^{\circ} \mathrm{C}$ until analysis of immunoglobulins. The concentrations of IgA, IgM and IgG were measured. Chicken plasma specific antibodies such as IgA (Bethyl laboratories, cat. no. E33-103), IgG (Bethyl laboratories, cat. no. E33-104) and IgM (Bethyl laboratories, cat. no. E33-102) concentrations were determined in diluted samples (1:100) by enzyme-linked immunosorbent assay 
(ELISA) using microtiter plates (NuncImmunoplate 96-well, cat. no. 446612) as per manufacturer's ELISA quantitation kits (Bethyl Laboratories Inc., Montgomery, TX, USA).

Measurement of the content of specific chicken antibodies was done by indirect ELISA as follows: microtiter plate wells were coated with $100 \mu \mathrm{l}$ of diluted coating antibody $(1: 200)$ to all wells and incubated for $2 \mathrm{~h}$ at room temperature (RT). After incubation, coated plates were washed with washing solution $\mathrm{pH} 8.0$ (0.05 M Tris, $0.15 \mathrm{M} \mathrm{NaCl}, 10 \%$ Tween 20) to eliminate excess capture antibodies. Wells were incubated with $200 \mu$ l blocking buffer pH 8.0 (0.05 M Tris, $0.15 \mathrm{M} \mathrm{NaCl}, 1 \% \mathrm{BSA})$ on a shaker for $30 \mathrm{~min}$ at RT to block nonspecific protein binding and then washed 3 times with washing solution.

For the determination of immunoglobulins (IgG, IgM, or IgA), plasma samples were diluted and $100 \mu \mathrm{l}$ of diluted plasma was added in triplicate. Plasma dilutions were 1:3000 for $\operatorname{IgM}, 1: 1000$ for $\operatorname{IgA}$ and 1:25,000 for IgG. Concentrations of IgG, IgM, and IgA in the standards were $6.25 \mathrm{mg} / \mathrm{ml}, 0.4 \mathrm{mg} / \mathrm{ml}$, and $0.38 \mathrm{mg} / \mathrm{ml}$ respectively. Standards were diluted for IgG ranging from $200 \mathrm{ng} / \mathrm{ml}$ to $3.12 \mathrm{ng} / \mathrm{ml}$, for IgM from $250 \mathrm{ng} / \mathrm{ml}$ to $3.9 \mathrm{ng} / \mathrm{ml}$ and for IgA from $1000 \mathrm{ng} / \mathrm{ml}$ to $15,625 \mathrm{ng} / \mathrm{ml}$. The concentrations of immunoglobulins in test plasma samples were determined using these standard curves. The plates were incubated for $1 \mathrm{~h}$ at RT and were washed three times in washing solution. $100 \mu \mathrm{l}$ of (horseradish-peroxidase) HRP detection anti-chicken IgM (A30-102P) was diluted 1:75,000 and for anti-chicken IgA (A30-103P) and IgG (A30-104P) were diluted 1:50,000 in conjugate diluent $\mathrm{pH} 8$ (0.05 M Tris, $0.15 \mathrm{M} \mathrm{NaCl}, 10 \%$ Tween 20) was added to each well and the plates were allowed to incubate for $1 \mathrm{~h}$ at RT. After incubation, to remove unbound peroxidase-conjugates, each well was washed with washing solution for 3 times. $100 \mu \mathrm{l}$ of (3,3,5,5-tetramethylbenzidine) TMB substrate was added to each well to determine bound peroxidase, and after incubation for 5-15 min in the dark at RT, $100 \mu \mathrm{l}$ of $1 \mathrm{M} \mathrm{H}_{2} \mathrm{SO}_{4}$ was added to each well to stop the TMB reaction. The optical density was measured at $450 \mathrm{~nm}$ and expressed as ng of IgA, IgM and IgG per ml of plasma with a microplate reader. Using the mean absorbance value for each sample, determines the corresponding concentration of immunoglobulins in $\mathrm{ng} / \mathrm{ml}$ from the standard curve.

\section{Gene expression of TNF- $a$ and NF-kB}

Liver tissue samples (approximately $30 \mathrm{mg}$ ) were homogenized in TRIzol ${ }^{\circ}$ Reagent (Invitrogen, Carlsbad CA, USA, cat. no. 15596-018). Then, RNA clean-up was performed and total RNA was extracted according to the manufacturer's protocol using SV Total RNA isolation system (Promega Corporation, Madison, WI, USA, cat. no. Z3105). Final RNA preparations were resuspended in RNase-free water and stored at $-80{ }^{\circ} \mathrm{C}$. The content of isolated RNA was quantified by UV-spectroscopy at $260 \mathrm{~nm} / 280 \mathrm{~nm}$ with a NanoDrop ${ }^{\circledR}$ ND-1000 Spectrophotometer (Thermo Fisher Scientific, Waltham, MA, USA). Further quality was assessed by Agilent 2100 bioanalyser (Agilent RNA 6000 Nano kit, Waldbronn, Germany) and more than 6.5 RNA integrity number values were considered for cDNA preparation.

Two mg of total RNA was reverse-transcribed using the cDNA Reverse Transcription Kit (Promega, cat. no. A3500) in a G-storm PCR System. After this, real-time PCR was performed with complementary DNA and genespecific primer pairs (TAG, Copenhagen A/S, Copenhagen, Denmark) mixed with LightCycler ${ }^{\circ} 480$ SYBR Green I Master mix (Roche Applied Science, Penzberg, Germany) in a LightCycler 480 real-time PCR system (Roche Applied Science). The cycling conditions included an initial heat step at $95{ }^{\circ} \mathrm{C}$ for $5 \mathrm{~min}$, denaturation at $95{ }^{\circ} \mathrm{C}$ for $10 \mathrm{~s}$, annealing temperatures described in Table 2 for each of the primers and product elongation at $72{ }^{\circ} \mathrm{C}$ for $20 \mathrm{~s}$ for 45 cycles. Following amplification, the melting curve was conducted on each sample to ensure that a single product was obtained using three-segment cycle of $95{ }^{\circ} \mathrm{C}$ for $5 \mathrm{~s}, 65^{\circ} \mathrm{C}$ for $1 \mathrm{~min}$ and $95{ }^{\circ} \mathrm{C}$ no hold for continuous-acquisition mode with a heating rate of $0.11{ }^{\circ} \mathrm{C} / \mathrm{s}$ and 5 acquisitions per $1{ }^{\circ} \mathrm{C}$ ). Characterization of the product size was, furthermore, confirmed by agarose gel electrophoresis and sequencing (Bechman coulter genomics Takeley, UK). Results were quantified based on the relative expression of the TNF- $\alpha$ and $N F-k B$ genes versus the housekeeping genes GAPDH and ACTB using advanced relative quantification (Efficiency method) by Light Cycler 480 Software release 1.50 SP4. The gene expression experiment was repeated 2 times chemically with consistent results and three replicates were used per sample each time.

Table 2 Genes and primers used in the study

\begin{tabular}{|c|c|c|c|c|}
\hline \multirow{2}{*}{$\begin{array}{l}\text { RNA target } \\
\text { gene }\end{array}$} & \multirow[t]{2}{*}{ Primer sequences $\left(5^{\prime}-3^{\prime}\right)$} & \multicolumn{2}{|l|}{ PCR Product } & \multirow{2}{*}{$\begin{array}{l}\text { Gene bank } \\
\text { Assess. No }\end{array}$} \\
\hline & & $\begin{array}{l}\text { Annealing } \\
\text { Temperature }\end{array}$ & $\begin{array}{l}\text { Amplicon } \\
\text { (bp) }\end{array}$ & \\
\hline$\overline{G A P D H}$ & & & & NM_204305.1 \\
\hline Forward & TGCTGCCCAGAACATCAT & $61{ }^{\circ} \mathrm{C}$ & 199 & \\
\hline Reverse & ATCAGCAGCAGCCTTCAC & & & \\
\hline$A C T B$ & & & & NM_205518.1 \\
\hline Forward & GTCCACCTTCCAGCAGATGT & $60^{\circ} \mathrm{C}$ & 169 & \\
\hline Reverse & ATAAAGCCATGCCAATCTCG & & & \\
\hline$N F-k B$ & & & & M86930.1 \\
\hline Forward & TTGCTGCTGGAGTTGATGTC & $60^{\circ} \mathrm{C}$ & 167 & \\
\hline Reverse & TTGCTGCTGGAGTTGATGTC & & & \\
\hline TNF- $a$ & & & & NM_204267.1 \\
\hline Forward & TTCAGATGAGTTGCCCTTCC & $59^{\circ} \mathrm{C}$ & 150 & \\
\hline Reverse & TCAGAGCATCAACGCAAAAG & & & \\
\hline
\end{tabular}




\section{Statistical analysis}

The data were analyzed using the GLM procedure of SAS (SAS Institute Inc., 2008) 9.2 version for windows considering the treatments (AgNP vs. non-supplemented control), the day of age (15, 22 and 30) and interactions between treatment and age. Tukey-Kramer significant different test was employed to test the separation of the means and differences were considered statistically significant when the $p \leq 0.05$.

\section{Results}

\section{Enumeration of bacteria}

There were no differences between birds receiving AgNP and the control group (Fig. 1) with respect to the numbers of C. jejuni, lactic acid bacteria, Enterococci, Clostridium perfringens, Escherichia coli, and Lactose negative enterobacteria in the contents of caecum, ileum and feces of the birds.

\section{The influence of AgNP on feed and water intake}

AgNP had no effect on the average daily water intake (ADWI), average daily feed intake (ADFI) and feed conversion ratio (FCR $=$ ADFI/ ADWG) (Table 3). The average daily weight gain (ADWG) was significantly lower in birds receiving AgNP compared to the control birds, in the periods $0-11$ days ( $p=0.007), 11-15$ days $(p=0.002)$ $15-22$ days $(p=0.003)$ but not in $22-30$ days $(p=0.728)$. The average amount of AgNP which single chicken received in the drinking water was $8.26 \mathrm{mg} / \mathrm{d}$ (Additional file 1: Table S1).

\section{The effect AgNP on chicken body weight and relative organ weights}

The body weight of birds supplemented with AgNP was significantly lower than that of control bids (Table 4).
Significant interactions between age and treatment were observed for the relative weight of bursa and spleen, where a lower relative bursa at age 15 , and for spleen at age 30 were noticed for AgNP group. Relative organ weights of heart and liver were not different between the control birds and birds supplemented with AgNP.

\section{AgNP response on PCV}

At days 15, 22 and 30 of age no significant difference between control birds and birds receiving AgNP was observed with respect to blood PCV levels (Fig. 2). Likewise, no effect of age was observed.

\section{Plasma immunoglobulin concentrations}

We observed significant interactions between treatment and age for the concentrations of $\operatorname{IgA}$, IgG and IgM in plasma (Fig. 3). At day 30, the plasma concentration of IgA was higher in birds supplemented with AgNP than in control birds, whereas the opposite effect was observed at age 15 and 22 days $(p=0.05$, Fig. 3a). At day 30 , the concentration of IgG in plasma was significantly lower in birds receiving AgNP as compared to the control birds (Fig. 3b). At age 15, plasma concentrations of IgM were higher in the AgNP group than in the control group (Fig. 3c), whereas at day 22 and 30, the concentrations of IgM were lower $(p<0.05)$.

\section{Gene expression of NF-kB and TNF- $a$}

The influence of AgNP on the mRNA $N F-\kappa B$ and $T N F-\alpha$ expression in liver tissue of $C$. jejuni infected chickens is shown in Fig. 4. Interestingly, at day 30, the levels of $N F-\kappa B$ (Fig. 4a-c) and TNF- $\alpha$ expression (Fig. 4b-d) were increased $(\mathrm{p}<0.05)$ in the group supplemented with AgNP compared to the control group.

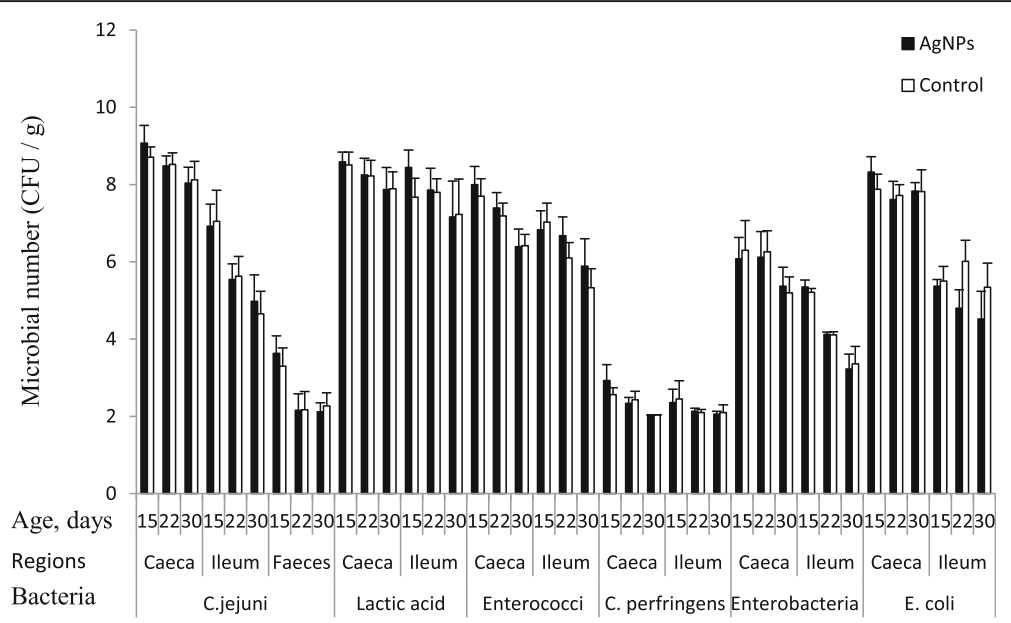

Fig. 1 Influence of AgNP administration in broiler chickens after challenge with C. jejuni on microbial profile in caeca, ileum and feces. At 15, 22, and 30 days of age, samples ( $n=30$ for each time point) were used for microbial count. Error bars represent the mean and standard errors of 6 isolators each with 15 birds 
Table 3 Effect of silver nanoparticles (AgNP) on daily feed and water intake, weight gain and feed conversion ratio of chickens infected with C. jejuni

\begin{tabular}{lllll}
\hline $\begin{array}{l}\text { Parameters } \\
\text { (g/bird) }\end{array}$ & \begin{tabular}{l} 
Mean \\
\cline { 3 - 4 } Control
\end{tabular} & AgNP & $\begin{array}{l}\text { Pooled } \\
\text { SE }\end{array}$ & $\begin{array}{l}\text { Treatment*Age } \\
p \text {-value }\end{array}$ \\
\hline $\begin{array}{lllll}\text { ADWI } \\
\text { Day 0-30 }\end{array}$ & 161 & 165 & 0.34 & 0.64 \\
ADFI & & & & 0.16 \\
Day 0-30 & 97.0 & 102 & 0.17 & \\
ADWG & & & & \\
Day 0-11 & $21.7^{\mathrm{a}}$ & $18.7^{\mathrm{b}}$ & & \\
Day 11-15 & $43.7^{\mathrm{a}}$ & $38.6^{\mathrm{b}}$ & & \\
Day 15-22 & $62.7^{\mathrm{a}}$ & $57.4^{\mathrm{b}}$ & & \\
Day 22-30 & 70.5 & 69.4 & & \\
Day 0-30 & 46.6 & 44.9 & 0.34 & \\
FCR & & & & \\
Day 0-30 & 1.97 & 2.22 & 0.03 & \\
\hline
\end{tabular}

*Indicates interaction

Values are mean of 6 isolators each with 15 birds

$S E$ pooled standard error, ADWI Average daily water intake (g per bird), ADFI

Average daily feed intake ( $\mathrm{g}$ per bird), $A D W G$ Average daily weight gain ( $\mathrm{g}$ per bird) and $F C R$ Feed conversion ratio

${ }^{a, b}$ values within rows with different superscripts are significantly different at $p<0.05$

\section{Discussion}

In vitro antibacterial tests against $C$. jejuni showed a minimal inhibitory concentration of AgNP at the level of 40 and $50 \mathrm{ppm}$. AgNP have an effect on the target microorganism in the absence of chickens. In the present in vivo experiment, $50 \mathrm{ppm}$ of AgNP was used because, prior to this experiment we carried out dose response studies to examine the antibacterial effect against C. jejuni of different concentrations of AgNP on chickens by chicken intestinal organ culture model (CIOC-model, Additional file 2: Table S2). The minimum inhibitory and minimum bactericidal concentration of silver nanoparticles on $C$. jejuni was determined by using the microtiter plate method (Additional file 3: Figure S1), showed bactericidal effect with minimum concentration of $50 \mathrm{ppm}$. We have evaluated samples of ileum, caecum and feces because of the uniformity of the gut microbiota in these segments. The caecum has a slow digesta passage rate, allowing to harbor a complex microbiome that has considerable effects on host nutrition and health [38]. The small intestinal region of the ileum has received attention since it is the principal site of nutrient absorption and microflora [39]. Furthermore, we focused on test samples at various time points because the caecal and ileal microflora changes in relation to age and dietary treatments $[38,39]$.

However, unexpectedly, AgNP did not change the microbial profile of caecum, ileum and feces of examined chickens (Fig. 1). These results are consistent with in vivo experiments with the microbial profile of young quails
Table 4 Effects of silver nanoparticles (AgNP) on cumulative body and relative organ weight gain $(\mathrm{g} / \mathrm{kg})$ in C. jejuni infected broiler chickens

\begin{tabular}{|c|c|c|c|c|}
\hline \multirow{2}{*}{$\begin{array}{l}\text { Parameters } \\
\text { (g/bird) }\end{array}$} & \multicolumn{2}{|l|}{ Mean } & \multirow{2}{*}{$\begin{array}{l}\text { Pooled } \\
\text { SE }\end{array}$} & \multirow{2}{*}{$\begin{array}{l}\text { Treatment*Age } \\
\text { p-value }\end{array}$} \\
\hline & Control & AgNP & & \\
\hline \multicolumn{5}{|l|}{$\overline{A W G}$} \\
\hline Age 15 & $380^{\mathrm{a}}$ & $318^{b}$ & & \\
\hline Age 22 & $788^{a}$ & $722^{b}$ & & \\
\hline Age 30 & $1424^{\mathrm{a}}$ & $1346^{b}$ & 0.305 & 0.013 \\
\hline \multicolumn{5}{|l|}{ Heart } \\
\hline Age 15 & 0.71 & 0.70 & & \\
\hline Age 22 & 0.62 & 0.66 & & \\
\hline Age 30 & 0.47 & 0.50 & 9.17 & 0.340 \\
\hline \multicolumn{5}{|l|}{ Bursa } \\
\hline Age 15 & $0.25^{a}$ & $0.20^{b}$ & & \\
\hline Age 22 & 0.21 & 0.22 & & \\
\hline Age 30 & 0.20 & 0.20 & 5.08 & 0.003 \\
\hline \multicolumn{5}{|l|}{ Spleen } \\
\hline Age 15 & 0.09 & 0.11 & & \\
\hline Age 22 & 0.07 & 0.07 & & \\
\hline Age 30 & $0.07^{\mathrm{a}}$ & $0.05^{b}$ & 2.31 & $<0.001$ \\
\hline \multicolumn{5}{|l|}{ Liver } \\
\hline Age 15 & 2.71 & 2.82 & & \\
\hline Age 22 & 2.52 & 2.56 & & \\
\hline Age 30 & 2.01 & 2.00 & 0.003 & 0.657 \\
\hline
\end{tabular}

Abnormalities At age 30, big gall bladder was found from 2 out of 15 birds in AgNP group

*Indicates interaction

$a, b$ values within rows with different superscripts are significantly different at $p<0.05$. SE - pooled standard error, AWG - average body weight gain.

The relative organ weights (weight of organ $/ 100 \mathrm{~g}$ live body weight). Values are mean of 6 isolators each with 15 birds

receiving hydrocolloids of AgNP administered with 5, 15 and $25 \mathrm{ppm}$ [29]. Moreover, another study demonstrated that supplying AgNP did not effectively rescue Salmonellamediated mortality in chickens but nanoscale silicate platelet (NSP) and its nanohybrid composite of AgNP/NSP effectively controlled the infection [40]. However, our present study was not similar with this study in terms of end point of examination, concentration of nanoparticles, bacterial infection time points and target bacterial species. The factors that could affect the present results might be the method of AgNP administration, although C. jejuni colonization in the intestinal tract depends on the number and diversity of environmental microorganisms, as well as influence of feedstuffs. The other possibilities could be the C. jejuni biofilm formation and adhesion to the host intestinal wall may provide protection against nanoparticles. The chicken intestinal mucus is able to attenuate $C$. jejuni virulence by inhibiting its ability to adhere and invade intestinal epithelial cells [41]. Furthermore, the antibacterial 


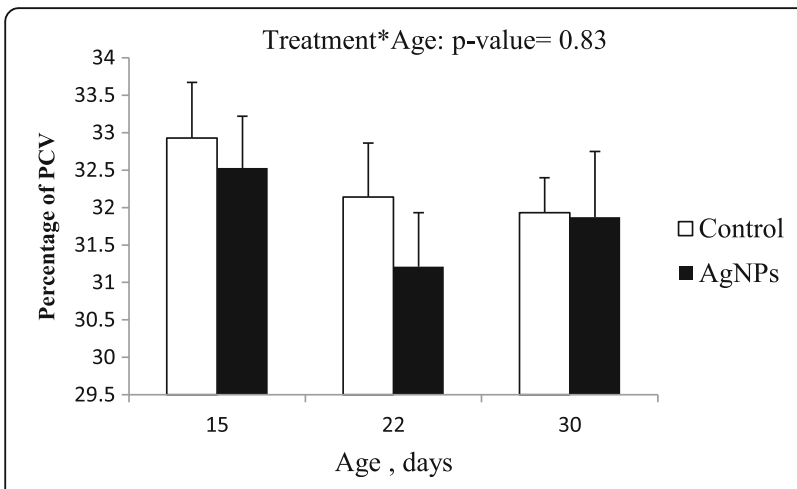

Fig. 2 Effect of silver nanoparticles (AgNP) on packed cell volume levels in chickens infected with C. jejuni. Error bars represent the mean values and standard errors of 6 isolators each with 15 birds

properties of AgNP could vanish inside the digestive tract environment of chickens, probably, due to AgNP agglomeration in the presence of low $\mathrm{pH}$ gastric acid. The obtained results may suggest that AgNP were gastro-sensitive, the stability and dispersion of AgNP in gastric acid is a critical factor for antibacterial activity. Once the particle enters a biological system, physical properties such as solubility, particle agglomeration, surface charge and particle-protein complex interactions might be different from those of the in vitro-measured properties. The loss of nanoparticles' properties may be due to the low colloidal stability and the reduction of reactive surfaces may affect the efficacy for controlling pathogens in a solution [42].

The reduction in cumulative body weight and relative organ weights of the spleen and bursa of birds supplemented with AgNP might be due to the effect of AgNP blocking the intestinal absorption of actively transported sugars and amino acids, and decreased protein digestibility through the small intestine where mainly enzymatic activity is present. Another possible reason might be the fact that the birds undergo more cellular stress and excessive cellular interactions with AgNP. It appears that $C$. jejuni colonization may lead to weight loss in grower chickens. The present results are consistent with decreased body and organ weights in chickens treated with $25 \mathrm{ppm}$ of AgNP at 42 days of age [43]. Moreover, the study of Asharani et al. [44] suggested that AgNP increase ROS production and interrupt ATP synthesis, leading to DNA damage and cell cycle arrest at G2/M phase. Park et al. [32] found that AgNP induce G1 phase arrest and a complete blockage of the $S$ phase, with the induction of apoptosis. The AgNP (10 ppm) injected into fertilized eggs on days 5, 11 and 17 of incubation did not influence the development of embryos

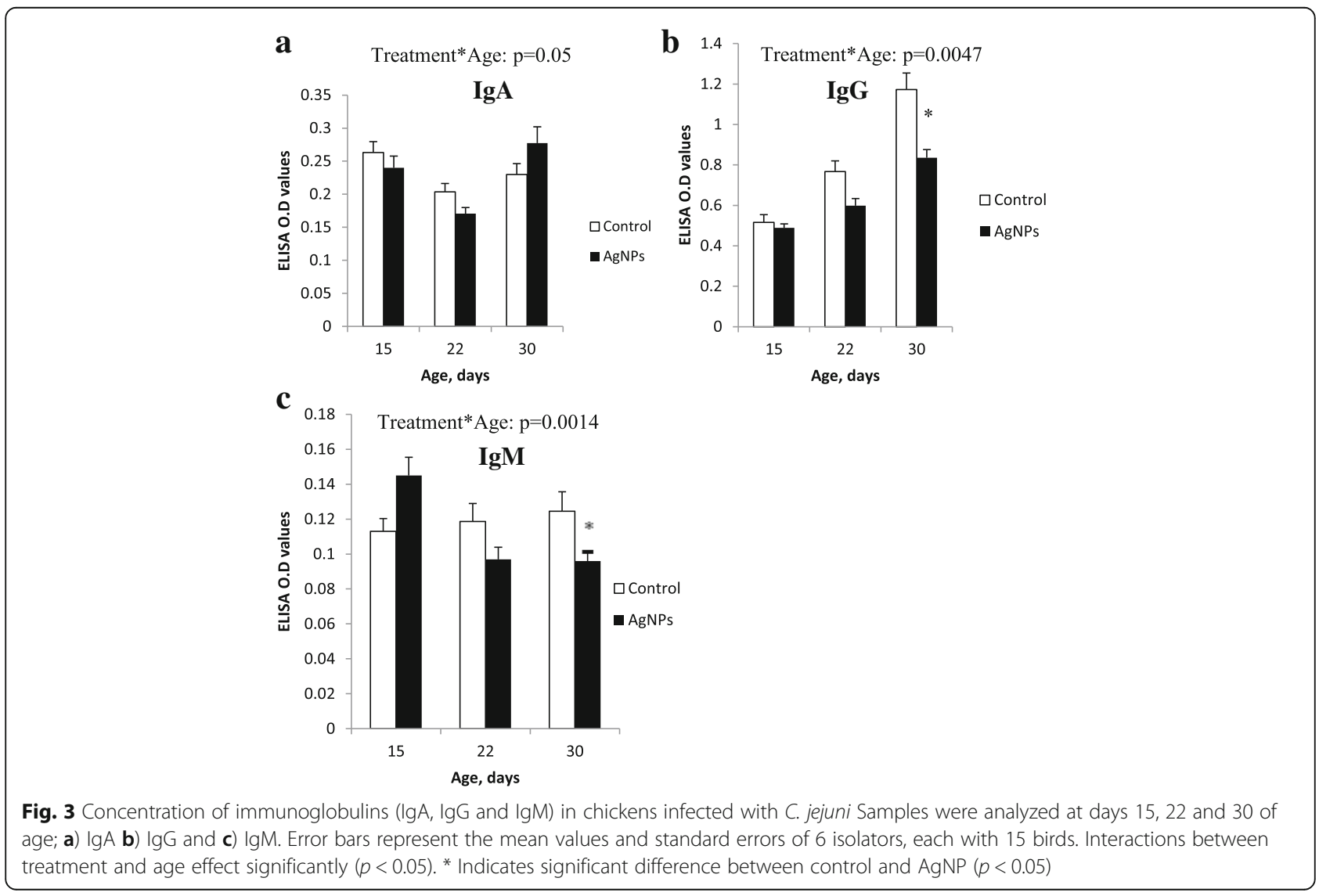



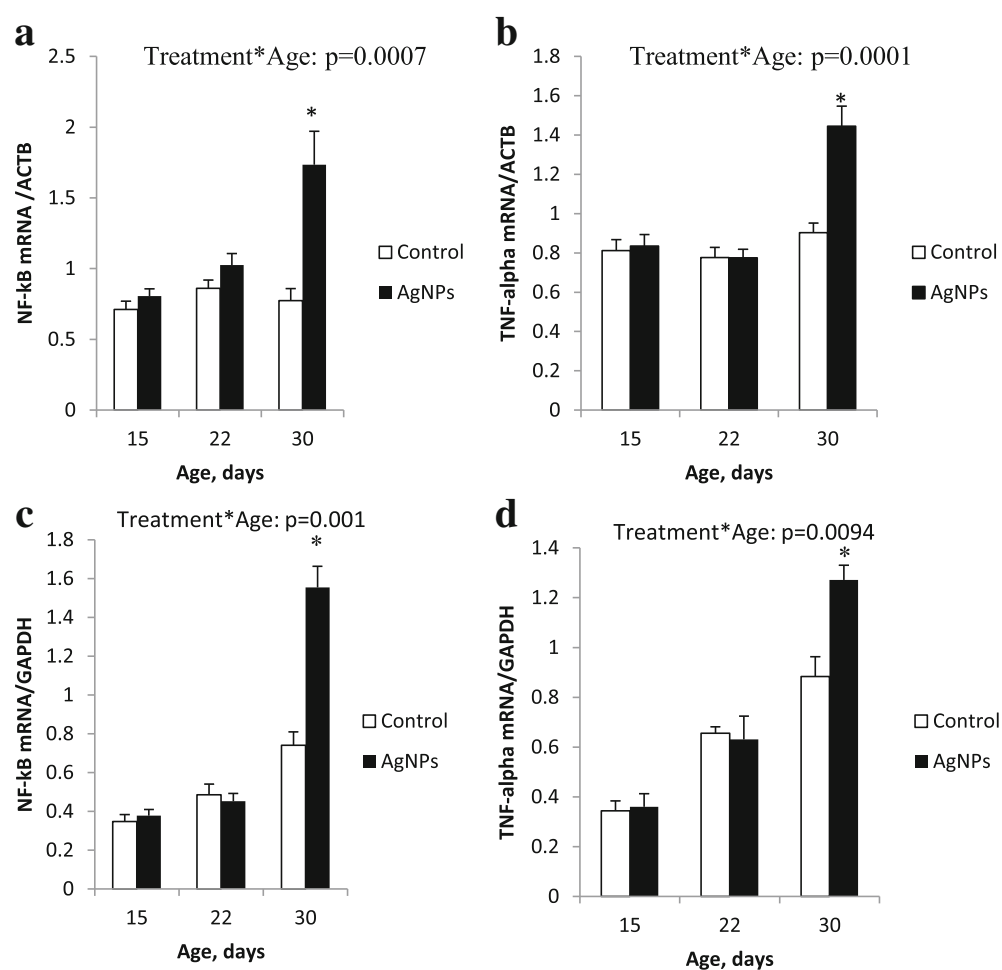

Fig. 4 The expression of mRNA NF-KB and TNF- $a$ normalized to the housekeeping genes ACTB and GAPDH in the liver tissue of chickens infected with C. jejuni. Samples were analyzed at days 15, 22 and 30 of age; a) NF-KB /ACTB, b) TNF-a /ACTB, c) NF-KB /GAPDH and d) TNF-a /GAPDH. Error bars represent the mean values and standard errors of 6 isolators, each with 15 birds. Interactions between treatment and age effect significantly $(p<0.05) .{ }^{*}$ Indicates significant difference between control and AgNP $(p<0.05)$

but decreased the number and size of lymph follicles in the bursa of Fabricius [45].

The PCV results indicated that the provision of AgNP did not influence the percentage of red blood cells (Fig. 2). On the other hand, it was reported that the oral administration of AgNP induced some changes in the red blood compartment, such as increased red blood cell count [46] and coagulation parameters [47].

The present results demonstrated age-related differences in immunoglobulin concentrations, which could probably be ascribed to the infection with $C$. jejuni on day 11 of age. Immunoglobulins are generally associated with immune resistance to extracellular bacteria and viruses or other foreign substances. Therefore, their levels might be most appropriate to study diseases caused by extracellular microorganisms [48]. Plasma immunoglobulin levels were measured following C. jejuni infection of chickens on days 15, 22 and 30 of age. Noticeable, significantly lower levels of IgG and IgM were observed in AgNP supplemented chickens (Fig. 3b-c). The decrease in the levels of IgG and IgM in AgNP birds might be due to the microbial colonization and provision of AgNP via drinking water. Importantly, the impaired $\mathrm{T}$-cell function might be a reason for reduced IgG levels. AgNP might impair intestinal actively transported sugars, amino acids, trace elements, and vitamins, and deficiencies of these nutrients may decrease antibody formation. Similar observations showed decreased plasma IgG levels in chickens treated with $10 \mathrm{ppm}$ and $20 \mathrm{ppm}$ AgNP but not infected with $C$. jejuni [49]. Reduction of bursa and spleen weights may be correlated to the decreased IgG levels. Therefore, the expression of immunological effects in this study was assumed to be the result of AgNP impairment. It could be that lymphocyte production and self- or nonself-antigen selection against $C$. jejuni infection changes with age, and could also be influenced by AgNP. Our results suggested that AgNP can diminish the activity of humoral immunity of broiler chickens by decreasing the levels of immunoglobulins in plasma.

In the present study, $N F-k B$ and $T N F-\alpha$ expression was determined in chicken liver tissue to evaluate whether or not AgNP could modify inflammation at the transcriptional level (Fig. 4). NF-kB and TNF- $\alpha$ expressions are important in Campylobacter colonization as $C$. jejuni primarily colonized the lower small intestine and caecum, where remarkable histopathologic and ultrastructural changes in the epithelium were noticed. In a novel rabbit model, the pathogen induced intestinal inflammation had increased levels of IFN- $\gamma$, TNF- $\alpha$, IL-1 $\beta$, IL-2, IL-6, IL-8, and IL-22 gene expression. In the acute 
phase, the bacteria induced a significant increase in the expression of the most pro-inflammatory genes [50]. The infection of human intestinal epithelium with Campylobacter results in activation of $N F-k B$, which is needed for the induction of pro-inflammatory genes [51]. We have recently observed that $T N F-\alpha$ mRNA expression was consistent with $50 \mathrm{ppm}$ when AgNP were injected into chicken embryos after LPS stimulation during the 19th day [52]. Results concerning the mRNA expression of $N F-k B$ were not in agreement with those of the chicken embryo liver [53]. We suppose that this could be due to the time of exposure, tissue specificity and route of administration of AgNP. However, our results confirm the pro-inflammatory activity of AgNP, which has been previously observed in chickens and mice $[54,55]$. Furthermore, an increased inflammatory response of the AgNP group in comparison with the control group indicates an over-immunostimulation activity of AgNP. The ability of nanoparticles to freely move into local lymphoid tissues and trigger antigen-presenting cells might be responsible for their immunostimulatory activity.

The exact mechanism and reason how and where AgNP induce pro-inflammatory effects are not known, but it has been reported that they stimulate production of reactive oxygen species (ROS), and thereby modulate intracellular calcium concentrations, activate transcription factors, and induce cytokine production [56]. The toxicity of nanoparticles is manifested by inflammation resulting from oxidative stress [57-59]. Recently, various studies with AgNP have been published, demonstrating conflicting results that silver nanoparticles are toxic $[44,59-63]$ or non-toxic [64-66]. Furthermore, they could be proinflammatory [47, 67-69] or anti-inflammatory agents $[27,28,65]$. Importantly, particle size-dependent effects of AgNP were observed with respect to cellular uptake, pro-inflammatory response and changes at the proteome level [70]. The $20 \mathrm{~nm}$ AgNP elucidated a higher inflammatory response than the $200 \mathrm{~nm}$ particles in Caco-2/TC7 cells. It might be that bigger particles have different transport rates, reduced interaction with the cellular membranes and are better retained in the gastrointestinal epithelial mucous layer than smaller particles. Thus, smaller particles may cross the mucus layer and reach the cells.

An increase in mRNA expression of inflammatory mediators and low IgG and IgM levels could be due to the nanoparticle uptake triggering cellular effects, leading to inflammatory responses. However, the conflicting results might indicate that AgNP have multiple cellular targets that vary among different cell type. These results are attributed to several confounding factors such as $\mathrm{pH}$ [71], continuous oral administration of AgNP, [47, 68] or high concentration, [28] or even the availability of free radicals to induce oxidative stress and damage cells [58]. We propose that nanoparticles time of exposure, route of administration, particles size, aggregate formation, and altered bio-distribution in the form of rapid clearance owing to non-specific pathogen clearance from the systemic circulation could serve as aided factors. One possible cause for the AgNP dependent initiation of inflammation could be the fact that they enhance the production of ROS. These oxygen-derived free radicals may lead to mitochondrial dysfunction, increased gene expression of inflammatory cytokines (TNF- $\alpha$ ) and activation of specific transcription factors (NF-kB). The absorption, distribution, metabolism, excretion, and toxicity of AgNP are largely dependent on their physicochemical properties and the surrounding environmental conditions. However, we were unable to find a mechanism involved in the pro-inflammatory pathway of AgNP in the present work and could not verify the presence of AgNP in the digestive organs.

\section{Conclusions}

Orally-administered AgNP via the drinking water (50 ppm) had no effect on the intestinal colonization of $C$. jejuni following infection and did not influence the intestinal microbial profile of broiler chickens. However, AgNP reduced body weight gain, lowered concentrations of plasma immunoglobulins and upregulated mRNA expression of TNF- $\alpha$ and NF- $k B$, indicating toxicity and impaired immune response. Thus, the use of orally administered AgNP might be harmful to the chicken health.

\section{Additional files}

\section{Additional file 1: Table S1. Average daily water intake and the concentrations of silver nanoparticles (AgNP) when chickens were infected with C. jejuni. (DOCX $13 \mathrm{~kb}$ )}

Additional file 2: Table S2. Antibacterial effect of silver nanoparticles (AgNP) against $C$. jejuni by using chicken intestinal organ culture model (ClOC-model). AgNP concentrations 10 ppm, 20 ppm were provided via drinking water, 40 ppm and 80 ppm were supplemented in intestinal organ culture. Bacterial count was done by standard plate count method. (DOCX $12 \mathrm{~kb}$ )

Additional file 3: Figure S1. Effect of silver nanoparticles (AgNP) on C. jejuni at various concentrations, using broth microdilution method by microtiter plate. Bacterial density was measured by the plate counter. D20 to D70 ppm means diluted AgNP concentration from stock solution, C80 and C50 ppm means stock AgNP solution. Media, with bacteria were considered as negative and positive controls. The mean values of 3 repetitions. 1a) Bacterial growth (Optical density (OD)) difference $=$ Average of bacteria - Average of media. 1b) Bacterial growth difference $(\%)=$ Bacterial growth difference / Average of bacteria. (DOCX $20 \mathrm{~kb}$ )

\section{Abbreviations}

ADFI: Average daily feed intake; ADWG: Average daily weight gain; ADWl: Average daily water intake; AgNP: Silver nanoparticles; C. jejuni: Camplylobacter jejuni;

CCDA: Charcoal cefoperazone deoxycholate agar; CIOC: Chicken intestinal organ culture; E. coli: Escherichia coli; ELISA: Enzyme-linked immunosorbent assay; FCR: Feed conversion ratio; HRP: Horseradish-peroxidase; Igs: Immunoglobulins; LAB: Lactic acid bacteria; MRS: de Man Rogosa Sharpe; PCV: Packed cell volume; RIN: RNA integrity number; ROS: Reactive oxygen species; RT: Room temperature; TEM: Transmission electron microscopy; TMB: 3,3,5,5-tetramethylbenzidine; TSC: Tryptose sulfite cycloserine 


\section{Funding}

This research work was supported by the Danish Agency for Science Technology and Innovation \# 2106-08/0025.

\section{Availability of data and materials}

Data supporting the findings is found in the main paper and additional supporting files. Raw data files will also be shared by the corresponding author upon request.

\section{Authors' contributions}

KPV performed the experiments, analyzed data and wrote the paper. $\mathrm{CL}$ and RGE designed and coordinated the study, and evaluated the performance and laboratory measurements (microbial and hematological profiles, immunological results). ES and MK contributed with interpretation of the results and helped drafting the manuscript. RKP helped in laboratory setup and gene expression studies. AC participated in the design and coordination and helped with drafting the manuscript. All authors read and approved the final manuscript.

\section{Ethics approval and consent to participate}

The experiments were performed in accordance with requirements of the Danish Ministry of Justice regarding housing and treatment of experimental animals (Law 726, September 1993). The experimental protocols were approved by the local ethics commission for experimentation on animals (Aarhus University, Denmark) prior to the study.

\section{Consent for publication}

Not applicable

\section{Competing interests}

All authors declare that they have no competing interests.

\section{Publisher's Note}

Springer Nature remains neutral with regard to jurisdictional claims in published maps and institutional affiliations.

\section{Author details}

${ }^{1}$ Department of Veterinary and Animal Sciences, University of Copenhagen, 1870 Frederiksberg, Denmark. ${ }^{2}$ Department of Animal Science, Aarhus University, 8830 Tjele, Denmark. ${ }^{3}$ Department of Animal Nutrition and Biotechnology, Warsaw University of Life Sciences, 02-786 Warsaw, Poland.

Received: 9 June 2017 Accepted: 18 December 2017

\section{Published online: 02 January 2018}

\section{References}

1. Modi CM, Mody SK, Patel HB, Dudhatra GB, Kumar A, Sheikh TJ. Growth promoting use of antimicrobial agents in animals. J Appl Pharm Sci. 2011; 01(08):33-6.

2. Hao H, Cheng G, Iqbal Z, Ai X, Hussain HI, Huang L, Dai M, Wang Y, Liu Z, Yuan Z. Benefits and risks of antimicrobial use in food-producing animals. Front Microbiol. 2014;5:288.

3. Niewold TA. The non-antibiotic anti-inflammatory effect of antimicrobial growth promotors, the real mode of action? A hypothesis Poult Sci. 2007;86:605-9.

4. Asai T, Kojima A, Harada K, Ishihara K, Takahashi T, Tamura Y. Correlation between the usage volume of veterinary therapeutic antimicrobials and resistance in Escherichia coli isolated from the feces of food-producing animals in Japan. Jpn J Infect Dis. 2005;58(6):369-72.

5. Bach Knudsen KE. The nutritional significance of "dietary fibre" analysis. Anim Feed Sci Tech. 2001;90(1-2):3-20.

6. Wiesner RS, Hendrixson DR, DiRita VJ. Natural transformation of Campylobacter jejuni requires components of a type II secretion system. J Bacterial. 2003;185(18):5408-18.

7. DANMAP 2013 report. Use of antimicrobial agents and occurrence of antimicrobial resistance in bacteria from food animals, food and humans in Denmark. http://www.danmap.org/downloads/reports.aspx. Accessed 6 Oct 2015.

8. Van Immerseel F, De Buck J, Pasmans F, Huyghebaert G, Haesebrouck F, Ducatelle R. Clostridium perfringens in poultry an emerging threat for animal and public health. Avian Pathol. 2004;33(6):537-49.

9. Chang C. The immune effects of naturally occurring and synthetic nanoparticles. J Autoimmun. 2010;34(3):234-46.
10. Zhang Y, Bai Y, Yan B. Functionalized carbon nanotubes for potential medicinal applications. Drug Discov Today. 2010;15(11-12):428-35.

11. Panacek A, Kvitek L, Prucek R, Kolar M, Vecerova R. Silver colloid nanoparticles: synthesis, characterization and their antibacterial activity. J Phys Chem B. 2006; 110(33):16248-53,

12. Lok CN, Ho CM, Chen R, He QY, Yu WY, Sun H, Tam PK, Chiu JF, Che CM. Silver nanoparticles: partial oxidation and antibacterial activities. J Biol Inorg Chem. 2007;12(4):527-34.

13. Morones JR, Elechiguerra JL, Camacho A, Holt K, Kouri JB, Ramírez JT, Yacaman MJ. The bactericidal effect of silver nanoparticles. Nanotechnol. 2005;16(10):2346-53.

14. Kim JS, Kuk E, Yu KN, Kim JH, Park SJ, Lee HJ, Kim SH, Park YK, Park YH, Hwang CY, Kim YK, Lee YS, Jeong DH, Cho MH. Antimicrobial effects of silver nanoparticles. Nanomed. 2007;3(1):95-101.

15. Yoon K, Hoon Byeon J, Park J, Hwang J. Susceptibility constants of Escherichia coli and Bacillus subtilis to silver and copper nanoparticles. Sci Total Environ. 2007;373(2-3):572-5.

16. Ayala-Núñez NV, Lara Villegas HH, Ixtepan Turrent LC, Padilla CR. Silver nanoparticles toxicity and bactericidal effect against methicillin-resistant Staphylococcus aureus: nanoscale does matter. Nanobiotechnol. 2009;5:2-9.

17. Alt $\mathrm{V}$, Bechert $\mathrm{T}$, Steinrucke $\mathrm{P}$, Wagener $\mathrm{M}$, Seidel $\mathrm{P}$, Dingeldein $\mathrm{E}$, Domann E, Schnettler R. An in vitro assessment of the antibacterial properties and cytotoxicity of nanoparticulate silver bone cement. Biomaterials. 2004;25(18):4383-91.

18. Sawosz E, Chwalibog A, Mitura K, Mitura S, Szeliga J, Niemiec T, Rupiewicz M, Grodzik M, Sokolowska A. Visualization of morphological interaction of diamond and silver nanoparticles with Salmonella Enteritidis and Listeria Monocytogenes. J Nanosci Nanotechnol. 2011;11:1-7.

19. Chen $D, X i T$, Bai J. Biological effects induced by nanosilver particles: in vivo study. Biomed Mater. 2007;2(3):126-8.

20. Rees JH, Gregson NA, Griffiths PL, Hughes RAC. Campylobacter jejuni and Guillain-Barré syndrome. Q J Med. 1993;86:623-34.

21. Nachamkin I. Microbiologic approaches for studying campylobacter in patients with Guillain-Barre syndrome. J Infect Dis. 1997;176(2):106-14.

22. Ketley JM. Pathogenesis of enteric infection by campylobacter. Microbiology. 1997;143(1):5-21

23. Gormley FJ, Strachan NJ, Reay K, MacKenzie FM, Ogden ID, Dallas JF, Forbes $\mathrm{KJ}$. Antimicrobial resistance profiles of campylobacter from humans, retail chicken meat, and cattle feces. Foodborne Pathog Dis. 2010;7(9):1129-31.

24. Sotiriou GA, Pratsinis SE. Antibacterial activity of nanosilver ions and particles. Environ Sci Technol. 2010;44(14):5649-54.

25. Dunn $\mathrm{K}$, Edwards-Jones $\mathrm{V}$. The role of Acticoat with nanocrystalline silver in the management of burns. Burns. 2004;30(Supp 1):S1-9.

26. Shrivastava S, Bera T, Roy A, Singh G, Ramachandrarao P, Dash D. Characterization of enhanced antibacterial effects of novel silver nanoparticles. Nanotechnol. 2007;18:225103.

27. Bhol KC, Schechter PJ. Topical nanocrystalline silver cream suppresses inflammatory cytokines and induces apoptosis of inflammatory cells in a murine model of allergic contact dermatitis. Br J Dermatol. 2005;152(6):1235-42.

28. Shin SH, Ye MK, Kim HS, Kang HS. The effects of nano-silver on the proliferation and cytokine expression by peripheral blood mononuclear cells. Int Immunopharmacol. 2007;7(13):1813-8.

29. Sawosz E, Binek M, Grodzik M, Zielinska M, Sysa P, Szmidt M, Niemiec T, Chwalibog A. Influence of hydrocolloidal silver nanoparticles on gastrointestinal microflora and morphology of enterocytes of quails. Arch Anim Nutr. 2007;61(6):441-51.

30. Sawosz E, Grodzik M, Zielinska M, Niemiec T, Olszanska B, Chwalibog A. Nanoparticles of silver do not affect growth, development and DNA oxidative damage in chicken embryos. Arch Geflügelk. 2009;73(3):S208-13.

31. Greulich C, Kittler S, Epple M, Muhr G, Koller M. Studies on the biocompatibility and the interaction of silver nanoparticles with human mesenchymal stem cells (hMSCs). Langenbeck's Arch Surg. 2009;394(3):495-502.

32. Park EJ, Yi J, Kim Y, Choi K, Park K. Silver nanoparticles induce cytotoxicity by a Trojan-horse type mechanism. Toxicol in Vitro. 2010;24(3):872-8.

33. Nygaard UC, Hansen JS, Samuelsen M, Alberg T, Marioara CD, Løvik M. Single-walled and multi-walled carbon nanotubes promote allergic immune responses in mice. Toxicol Sci. 2009;109(1):113-23.

34. Mitchell LA, Lauer FT, Burchiel SW, McDonald JD. Mechanisms for how inhaled multi-walled carbon nanotubes suppress systemic immune function in mice. Nat Nanotechnol. 2009;4(7):451-6. 
35. Yamaguchi A, Fujitani T, Ohyama K, Nakae D, Hirose A, Nishimura T, Ogata A. Effects of sustained stimulation with multi-wall carbon nanotubes on immune and inflammatory responses in mice. J Toxicol Sci. 2012;37(1):177-89.

36. Wang X, Podila R, Shannahan JH, Rao AM, Brown JM. Intravenously delivered graphene nanosheets and multi-walled carbon nanotubes induce site specific Th2 inflammatory responses via the IL-33/ST2 axis. Int J Nanomedicine. 2013;8(3):1733-48.

37. Engberg RM, Hedemann MS, Leser TD, Jensen BB. Effect of zinc bacitracin and salinomycin on intestinal microflora and performance of broilers. Poult Sci. 2000;79(9):1311-9.

38. Pan D, Yu Z. Intestinal microbiome of poultry and its interaction with host and diet. Gut Microbes. 2014;5(1):108-19.

39. Knarreborg A, Simon MA, Engberg RM, Jensen BB, Tannock GW. Effects of dietary fat source and subtherapeutic levels of antibiotic on the bacterial community in the ileum of broiler chickens at various ages. Appl Environ Microbiol. 2002;68(12):5918-24.

40. Chiao SH, Lin SH, Shen Cl, Liao JW, Bau IJ, Wei JC, Tseng LP, Hsu SH, Lai PS, Lin SZ, Lin JJ, Su HL. Efficacy and safety of nanohybrids comprising silver nanoparticles and silicate clay for controlling salmonella infection. Int J Nanomedicine. 2012;7:2421-32

41. Alemka A, Whelan S, Gough R, Clyne M, Gallagher ME, Carrington SD, Bourke B. Purified chicken intestinal mucin attenuates Campylobacter jejuni pathogenicity in vitro. J Med Microbiol. 2010;59:898-903.

42. Sondi I, Salopek-Sondi B. Silver nanoparticles as antimicrobial agent: a case study on E. Coli as a model for gram-negative bacteria. J Colloid Interface Sci. 2004;275(1):177-82.

43. Ahmadi F, Kurdestany AH. The impact of silver nano particles on growth performance, lymphoid organs and oxidative stress indicators in broiler chicks. Global Veterinaria. 2010;5(6):366-70.

44. Asharani PV, Lian Wu Y, Gong Z, Valiyaveettil S. Toxicity of silver nanoparticles in zebrafish models. Nanotechnol. 2008;19(25):255102-10.

45. Grodzik M, Sawosz E. The influence of silver nanoparticles on chick embryo development and bursa of Fabricius morphology. J Anim Feed Sci. 2006; 15(1):111-4.

46. Hillery AM, Jani PU, Florence AT. Comparative, quantitative study of lymphoid and non-lymphoid uptake of $60 \mathrm{~nm}$ polystyrene particles. J Drug Target. 1994;2(2):151-6

47. Kim YS, Kim JS, Cho HS, Rha DS, Kim JM, Park JD, Choi BS, Lim R, Chang HK, Chung $Y H$, Kwon IH, Jeong J, Han BS, Yu IJ. Twenty-eight-day oral toxicity, genotoxicity, and gender-related tissue distribution of silver nanoparticles in Sprague-Dawley rats. Inhal Toxicol. 2008;20(6):575-83.

48. Sarker N, Tsudzuki M, Nishibori M, Yasue H, Yamamoto Y. Cell-mediated and humoral immunity and phagocytic ability in chicken lines divergently elected for serum immunoglobulin M and G levels. Poult Sci. 2000;79(12):1705-9.

49. Pineda L, Chwalibog A, Sawosz E, Lauridsen C, Engberg R, Elnif J, Hotowy A, Sawosz F, Gao Y, Ali A, Moghaddam HS. Effect of silver nanoparticles on growth performance, metabolism and microbial profile of broiler chickens. Arch Anim Nutr. 2012;66(5):416-29.

50. Shang Y, Ren F, Song Z, Li Q, Zhou X, Wang X, Xu Z, Bao G, Wan T, Lei T, Wang $N$, Jiao XA, Huang J. Insights into campylobacter jejuni colonization and enteritis using a novel infant rabbit model. Sci Rep. 2016;6(28737):1-12. doi: 10.1038/srep28737.

51. Zheng J, Meng J, Zhao S, Singh R, Song W. Campylobacter-induced interleukin-8 secretion in polarized human intestinal epithelial cells requires Campylobacter-secreted cytolethal distending toxin- and toll-like receptormediated activation of NFkappaB. Infect Immun. 2008;76:4498-508.

52. Bhanja SK, Hotowy A, Mehra M, Sawosz E, Pineda L, Vadalasetty KP, Kurantowicz N, Chwalibog A. In ovo administration of silver nanoparticles and/or amino acids influence metabolism and immune gene expression in chicken embryos. Int J Mol Sci. 2015;16:9484-503.

53. Sawosz E, Grodzik M, Lisowski P, Zwierzchowski L, Niemiec T, Zielińska M, Szmidt M, Chwalibog A. Influence of hydrocolloids of ag, au, and ag/cu alloy nanoparticles on the inflammatory state at transcriptional level. Bull Vet Inst Pulawy. 2010;54:81-5.

54. Loghman A, Iraj SH, Naghi DA, Pejman M. Histopathology and apoptotic effect of nanosilver in liver of broiler chickens. Afr J Biotechnol. 2012;11(22):6207-11.

55. Małaczewska J. The effect of silver nanoparticles on splenocyte activity and selected cytokine levels in the mouse serum at early stage of experimental endotoxemia. Pol J Vet Sci. 2011;14(4):597-604.

56. Brown DM, Donaldson K, Borm PJ, Schins RP, Dehnhardt M, Gilmour P, Jimenez LA, Stone V. Calcium and ROS-mediated activation of transcription factors and TNF-alpha cytokine gene expression in macrophages exposed to ultrafine particles. Am J Physiol Lung Cell Mol Physiol. 2004;286(2):L344-53.

57. Su HL, Chou CC, Hung DJ, Lin SH, Pao IC, Lin JH, Huang FL, Dong RX, Lin JJ. The disruption of bacterial membrane integrity through ROS generation induced by nanohybrids of silver and clay. Biomaterials. 2009;30:5979-87.

58. Park EJ, Yoon J, Choi K, Yi J, Park K. Induction of chronic inflammation in mice treated with titanium dioxide nanoparticles by intratracheal instillation. Toxicology. 2009;260(1-3):37-46.

59. Carlson C, Hussain SM, Schrand AM, Braydich-Stolle LK, Hess KL, Jones RL, Schlager JJ. Unique cellular interaction of silver nanoparticles: size-dependent generation of reactive oxygen species. J Phys Chem B. 2008;112(43):13608-19.

60. Ahamed M, Karns M, Goodson M, Rowe J, Hussain SM, Schlager JJ, Hong Y. DNA damage response to different surface chemistry of silver nanoparticles in mammalian cell. Toxicol Appl Pharmacol. 2008;233(3):404-10.

61. Park S, Lee YK, Jung M, Kim KH, Eun-Kyung Ahn NC, Lim Y, Lee KH. Cellular toxicity of various inhalable metal nanoparticles on human alveolar epithelial cells. Inhal Toxicol. 2007;19(1):59-65.

62. Yen HJ, Hsu SH, Tsai CL. Cytotoxicity and immunological response of gold and silver nanoparticles of different sizes. Small. 2009;5(13):1553-61.

63. Vandebriel RJ, Tonk EC, de la Fonteyne-Blankestijn LJ, Gremmer ER, Verharen $H W$, van der Ven LT, van Loveren $H$, de Jong WH. Immunotoxicity of silver nanoparticles in an intravenous 28-day repeated-dose toxicity study in rats. Part and Fibre Toxicol. 2014;11:21.

64. Ji JH, Jung JH, Kim SS, Yoon JU, Park JD, Choi BS, Chung YH, Kwon $\|_{\text {, }}$ Jeong J, Han BS, Shin JH, Sung JH, Song KS, Yu IJ. Twenty-eight-day inhalation toxicity study of silver nanoparticles in Sprague-Dawley rats. Inhal Toxicol. 2007;19(10):857-71.

65. Bhol KC, Schechter PJ. Effects of nanocrystalline silver (NPI 32101) in a rat model of ulcerative colitis. Dig Dis Sci. 2007;52(10):2732-42.

66. Sung JH, Ji JH, Park JD, Yoon JU, Kim DS, Jeon KS, Song MY, Jeong J, Han BS, Han JH, Chung YH, Chang HK, Lee JH, Cho MH, Kelman BJ, Yu IJ. Subchronic inhalation toxicity of silver nanoparticles. Toxicol Sci. 2009;108(2):452-61.

67. Trickler WJ, Lantz SM, Murdock RC, Schrand AM, Robinson BL, Newport GD, Schlager JJ, Oldenburg SJ, Paule MG, Slikker W, Hussain SM, Ali SF. Silver nanoparticles induced blood-brain barrier inflammation and increased permeability in primary rat brain microvessel endothelial cells. Toxicol Sci. 2010;118(1):160-70.

68. Park EJ, Bae E, Yi J, Kim Y, Choi K, Leed SH, Yoon J, Lee BC, Park K. Repeateddose toxicity and inflammatory responses in mice by oral administration of silver nanoparticles. Environ Toxicol Pharmacol. 2010;30(2):162-8.

69. Chen X, Schluesener HJ. Nanosilver: a nanoproduct in medical application. Toxicol Lett. 2008;176(1):1-12.

70. Georgantzopoulou A, Serchi T, Cambier S, Leclercq CC, Renaut J, Shao J, Kruszewski M, Lentzen E, Grysan P, Eswara S, Audinot JN, Contal S, Ziebel J, Guignard C, Hoffmann L, Murk AJ, Gutleb AC. Effects of silver nanoparticles and ions on a co-culture model for the gastrointestinal epithelium. Part and Fibre Toxicol. 2016;13:9.

71. Nadworny PL, Wang JF, Tredget EE, Burrell RE. Anti-inflammatory activity of nanocrystalline silver-derived solutions in porcine contact dermatitis. J Inflamm. 2010;7(13):1-20.

\section{Submit your next manuscript to BioMed Central and we will help you at every step:}

- We accept pre-submission inquiries

- Our selector tool helps you to find the most relevant journal

- We provide round the clock customer support

- Convenient online submission

- Thorough peer review

- Inclusion in PubMed and all major indexing services

- Maximum visibility for your research

Submit your manuscript at www.biomedcentral.com/submit 